\title{
Penurunan Ion Besi (Fe) dan Mangan (Mn) dalam Air dengan Serbuk Gergaji Kayu Kamper
}

\author{
Istifiarti Mandasari dan Alfan Purnomo \\ Jurusan Teknik Lingkungan, Fakultas Teknik Sipil dan Perencanaan, Institut Teknologi Sepuluh \\ Nopember (ITS) \\ Jl. Arief Rahman Hakim, Surabaya 60111 Indonesia \\ e-mail: alfan_purnomo@enviro.its.ac.id
}

\begin{abstract}
Abstrak-Air tanah mengandung berbagai mineral, antara lain besi dan mangan. Besi dan mangan yang berlebihan dalam air memerlukan pengolahan. Salah satu pengolahan yang sesuai adalah adsorpsi. Serbuk gergaji kayu memiliki kemampuan sebagai adsorben karena mengandung selulosa. Serbuk gergaji kayu diaktivasi terlebih dahulu dengan variasi pencucian akuades dan aktivasi kimia ( $\mathrm{HCl}-\mathrm{NaOH}$ ). Masing-masing larutan $\mathrm{Fe}$ dan Mn sebanyak $75 \mathrm{ml}$ dikontakkan dengan adsorben teraktivasi dengan dosis $6 \mathrm{gr} / \mathrm{L}$ dalam waktu $15 ; 30 ; 45 ; 60 ; 75 ; 90 ; 105$; dan 120 menit. Diperoleh kapasitas adsorpsi terbesar Fe $0,179 \mathrm{mg} / \mathrm{g}$ dan Mn 0,095 mg/g dengan adsorben teraktivasi kimia pada waktu 15 menit. Adsorben dikontakkan dengan larutan Fe konsentrasi 2,$6 ; 2,8 ; 3,0 ; 3,2$; dan $3,4 \mathrm{mg} / \mathrm{L}$ selama 15 menit dan diperoleh kapasitas adsorpsi maksimum terbesar $0,182 \mathrm{mg} / \mathrm{g}$ dengan rata-rata efisiensi removal $22,13 \%$ pada adsorben teraktivasi kimia. Adsorben dikontakkan dengan larutan Mn konsentrasi 5; 6; 7; 8; dan 9 mg/L selama 15 menit dan diperoleh kapasitas adsorpsi maksimum terbesar $1,698 \mathrm{mg} / \mathrm{g}$ dengan ratarata efisiensi removal $\mathbf{9 8 , 5 1 \%}$ pada adsorben teraktivasi kimia. Adsorben dengan aktivasi kimia menunjukkan kapasitas adsorpsi terbesar dalam menurunkan kadar Fe dan Mn.
\end{abstract}

Kata Kunci-Adsorpsi, besi, mangan, serbuk gergaji kayu

\section{PENDAHULUAN}

$I^{2}$ $\mathrm{ON}$ besi $(\mathrm{Fe})$ dan mangan $(\mathrm{Mn})$ bervalensi dua umumnya terdapat dalam air tanah secara bersamaan. Fe dan $\mathrm{Mn}$ dalam air dapat menyebabkan kekeruhan, korosi, kesadahan. Fe dan Mn juga menyebabkan warna kekuningan pada cucian dan alat plambing [1]. Teknologi yang umum digunakan untuk menyisihkan $\mathrm{Fe}$ dan $\mathrm{Mn}$ meliputi teknologi membran, adsorpsi, pertukaran ion, dan presipitasi. Adsorpsi merupakan salah satu proses pengolahan air yang efektif dan sering digunakan untuk menghilangkan logam berat [2].

Serbuk gergaji kayu mengandung lignin, selulosa, dan hemiselulosa sehingga serbuk gergaji kayu berpotensi sebagai penyerap ion logam [3]. Gugus $\mathrm{OH}$ pada selulosa dan hemiselulosa menyebabkan terjadinya sifat polar pada adsorben tersebut. Dengan demikian, selulosa dan hemiselulosa lebih kuat menyerap zat yang bersifat polar daripada zat yang kurang polar [4]. Salah satu jenis kayu yang mengandung selulosa yang tinggi yaitu kayu kamper dengan kandungan selulosa sebesar 60\% [5].

Berbagai faktor seperti luas permukaan, ukuran pori, jumlah pori, dan adanya gugus fungsi pada permukaan mempengaruhi kapasitas adsorpsi [6]. Hal ini menuntun pada modifikasi adsorben sehingga adsorben memiliki sifat fisik dan kimia untuk meningkatkan kemampuan pengambilan ion logam dari larutan. Aktivasi bertujuan untuk memodifikasi bagian permukaan adsorben [7]. Aktivasi dapat dilakukan dengan cara fisika, fisika-kimia, atau kimia. Oleh karena itu, perlu dilakukan suatu penelitian mengenai proses adsorpsi $\mathrm{Fe}$ dan Mn dengan adsorben variasi pencucian akuades dan aktivasi kimia. Penelitian ini bertujuan untuk mengetahui metode aktivasi terbaik untuk adsorben serbuk gergaji kayu kamper dalam proses adsorpsi Fe dan Mn dalam air.

\section{METODE PENELITIAN}

\section{A. Penelitian Pendahuluan}

Penelitian pendahuluan yang dilakukan adalah penentuan ukuran adsorben. Penentuan ukuran adsorben dilakukan dengan menggunakan analisis ayakan untuk mengetahui gradasi adsorben serta menyeragamkan ukuran adsorben yang digunakan. Adsorben yang digunakan adalah adsorben dengan persentase berat tertahan terbesar yaitu adsorben ukuran 20 mesh.

\section{B. Pembuatan Larutan Fe dan Mn}

Penelitian menggunakan larutan $\mathrm{Fe}$ dan $\mathrm{Mn}$ buatan (artificial). Konsentrasi larutan $\mathrm{Fe}$ yang digunakan untuk analisis sebesar 2,6; 2,8; 3,0; 3,2; dan 3,4 mg/L. Konsentrasi larutan Mn yang digunakan untuk analisis sebesar 5,0; 6,0; 7,0; 8,0; dan 9,0 mg/L.

\section{Aktivasi Adsorben}

Aktivasi adsorben dilakukan dengan dua variasi, yaitu adsorben yang dicuci dengan akuades serta adsorben dengan aktivasi kimia $\mathrm{HCl}-\mathrm{NaOH}$. Sebagai variabel kontrol, digunakan adsorben tanpa aktivasi.

Adsorben sebanyak \pm 100 gram dicuci dengan akuades menggunakan magnetic stirrer kecepatan 200 rpm selama 30 menit. Adsorben disaring dan dikeringkan di dalam oven dengan suhu $60^{\circ} \mathrm{C}$ selama 24 jam hingga kering merata.

Adsorben untuk aktivasi kimia diambil sebanyak \pm 100 gram dan dicuci dengan akuades menggunakan magnetic 
stirrer kecepatan $200 \mathrm{rpm}$ selama 30 menit. Adsorben selanjutnya dicuci dengan larutan $\mathrm{HCl} 1 \mathrm{M}$ menggunakan magnetic stirrer kecepatan $200 \mathrm{rpm}$ selama 30 menit. Adsorben disaring dan dicuci kembali beberapa kali dengan akuades hingga $\mathrm{pH}$ mendekati 7 . Adsorben direndam di dalam larutan $\mathrm{NaOH} 1 \mathrm{M}$ selama 24 jam, dan disaring dengan kain saringan. Adsorben selanjutnya dicuci beberapa kali dengan akuades hingga $\mathrm{pH}$ mendekati 7 dan disaring dengan kain saringan selanjutnya dikeringkan di dalam oven dengan suhu $60^{\circ} \mathrm{C}$ selama 24 jam hingga kering merata.

\section{Analisis Waktu Kontak Adsorben}

Larutan $\mathrm{Fe}$ yang digunakan dengan konsentrasi $3,0 \mathrm{mg} / \mathrm{L}$ dan $\mathrm{Mn}$ 0,7 mg/L. Penentuan waktu kontak dilakukan dengan mengambil larutan $\mathrm{Fe}$ sebanyak $75 \mathrm{ml}$ dan dimasukkan ke dalam 8 erlenmeyer $250 \mathrm{ml}$ yang berbeda, kemudian dikontakkan dengan adsorben dengan dosis $6 \mathrm{gr} / \mathrm{L}$. Larutan selanjutnya diaduk dengan shaker pada kecepatan $200 \mathrm{rpm}$ selama 15, 30, 45, 60, 75, 90, 105, dan 120 menit. Perlakuan ini dilakukan dengan masing-masing variasi aktivasi pencucian akuades, aktivasi kimia, maupun tanpa aktivasi. Penentuan waktu kontak $\mathrm{Mn}$ dilakukan dengan cara yang sama menggunakan larutan $\mathrm{Mn}$ dengan konsentrasi 0,7 mg/L. Masing-masing larutan selanjutnya disaring dan dianalisis konsentrasi Fe dan Mn akhir. Hasil analisis konsentrasi akhir Fe dan Mn digunakan untuk menghitung kapasitas adsorpsi.

\section{E. Analisis Kapasitas Adsorpsi}

Larutan Fe yang digunakan dengan konsentrasi 2,6; 2,8; 3,0; 3,2; dan 3,4 mg/L. Masing-masing larutan diambil sebanyak $75 \mathrm{ml}$ dan dimasukkan ke dalam Erlenmeyer $250 \mathrm{ml}$ yang berbeda-beda. Masing-masing larutan dikontakkan dengan adsorben dengan dosis $6 \mathrm{gr} / \mathrm{L}$ menggunakan shaker kecepatan 200 rpm selama waktu kontak yang diperoleh sebelumnya. Perlakuan ini dilakukan dengan masing-masing adsorben dengan pencucian akuades, aktivasi kimia, maupun tanpa aktivasi. penentuan kapasitas adsorpsi Mn dilakukan dengan cara yang sama menggunakan larutan Mn dengan konsentrasi 5,$0 ; 6,0 ; 7,0 ; 8,0 ;$ dan $9,0 \mathrm{mg} / \mathrm{L}$.

\section{HASIL DAN DISKUSI}

\section{A. Proses Aktivasi Adsorben}

Aktivasi adsorben bertujuan untuk memodifikasi bagian permukaan adsorben sehingga kapasitas adsorpsi dapat meningkat. Variasi aktivasi pertama yaitu pencucian dengan akuades. Pencucian adsorben yang mengandung selulosa dengan akuades dilakukan untuk menghilangkan komponenkomponen non selulosa yang menempel pada adsorben [8]. Selanjutnya adsorben dikeringkan dalam oven dengan suhu $60^{\circ} \mathrm{C}$ selama 24 jam hingga kering merata. Pemanasan dengan suhu lebih dari $105^{\circ} \mathrm{C}$ dapat mengakibatkan penyusutan volume, penutupan pori-pori adsorben dan dapat mengurangi kapasitas adsorpsi adsorben [9].

Aktivasi kimia dilakukan dengan menggunakan larutan $\mathrm{HCl}$ dan larutan $\mathrm{NaOH}$. Pencucian dengan larutan asam bertujuan untuk menghilangkan mineral-mineral asam serta pengotor yang menempel pada adsorben [10]. Perendaman adsorben dengan larutan $\mathrm{NaOH}$ bertujuan agar terjadi delignifikasi pada adsorben. Fungsi delignifikasi adalah melarutkan senyawasenyawa seperti lignin yang dapat menghambat proses adsorpsi. Hal ini terjadi karena keberadaan llignin akan menghalangi proses transfer ion ke sisi aktif adsorben. Larutan $\mathrm{NaOH}$ akan memecah ikatan selulosa dengan lignin [11]. Ion $\mathrm{OH}^{-}$dari $\mathrm{NaOH}$ akan memutus ikatan-ikatan dari struktur dasar lignin sehingga lignin akan mudah larut.

\section{B. Analisis Karakteristik Gugus Fungsional Adsorben}

Analisis gugus fungsional adsorben dilakukan dengan uji Fourier Transform Infra Red (FTIR). Uji FTIR pada adsorben diperlukan untuk mengetahui gugus fungsi yang terkandung dalam adsorben. Uji FTIR pada penelitian ini menggunakan Shimadzu spektrofotometer dengan spektrum infra merah sedang (angka gelombang 400-4000 $\mathrm{cm}^{-1}$ ).

Uji FTIR menunjukkan keberadaan gugus fungsi dengan merepresentasikan melalui peak besar serapan spektrum \% transmitan (sumbu Y) yang terbentang pada suatu angka gelombang (sumbu X). Setiap jenis gugus fungsi memiliki bentang angka gelombang tersendiri. Penentuan jenis gugus fungsi dapat ditentukan dengan lokasi peak serapan spektrum $\%$ transmitan yang terdapat pada suatu angka gelombang. Gugus fungsi yang diperlukan dalam adsorpsi logam-logam adalah gugus fungsi hidroksil (-OH).

Hasil uji FTIR pada adsorben tanpa aktivasi menghasilkan gugus fungsi pada Gambar 1.

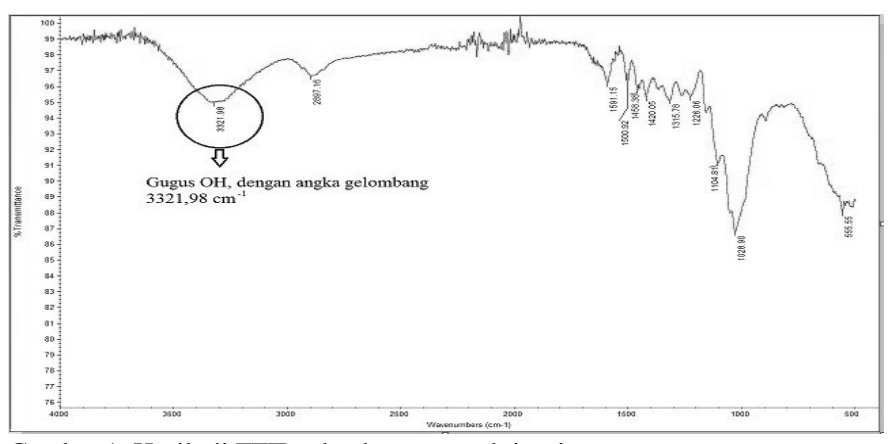

Gambar 1. Hasil uji FTIR adsorben tanpa aktivasi

Hasil uji FTIR pada adsorben dengan pencucian akuades menghasilkan gugus fungsi pada Gambar 2.

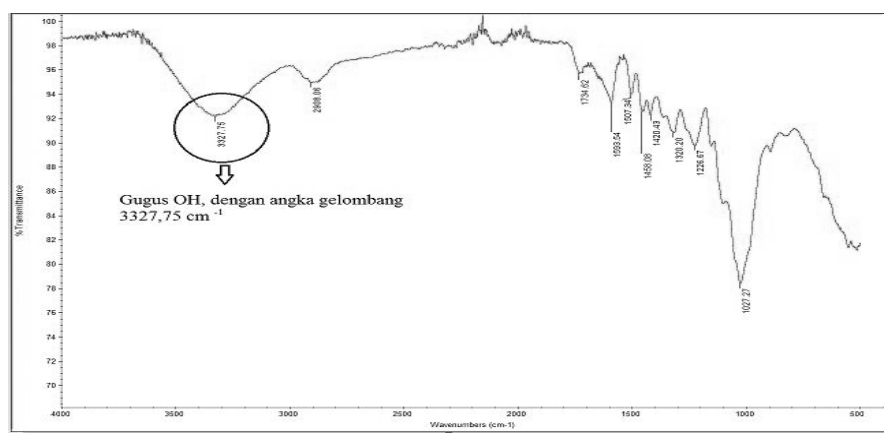

Gambar 2. Hasil uji FTIR adsorben dengan pencucian akuades 
Hasil uji FTIR pada adsorben dengan aktivasi kimia menghasilkan gugus fungsi pada Gambar 3 .

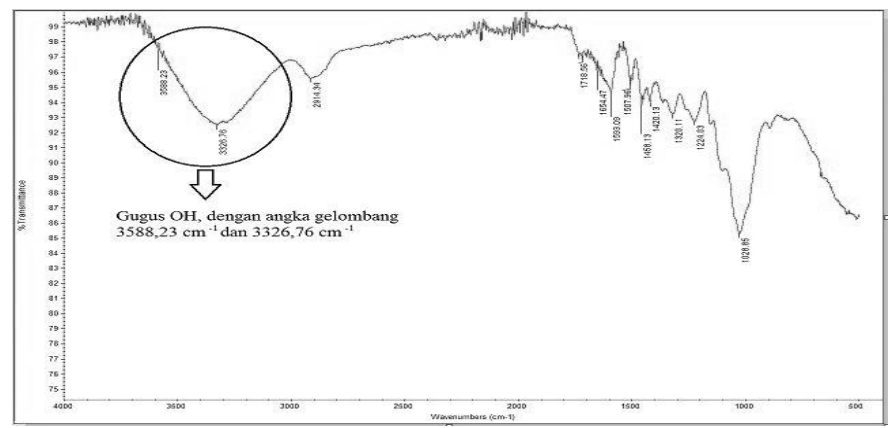

Gambar 3. Hasil uji FTIR adsorben aktivasi kimia

Berdasarkan hasil uji FTIR pada Gambar 1, 2, dan 3, diketahui bahwa seluruh adsorben dengan variasi metode aktivasi masih memiliki gugus hidroksil (-OH). Gugus hidroksil yang terkandung dalam masing-masing jenis adsorben menunjukkan bahwa setiap jenis adsorben dapat digunakan sebagai adsorben ion logam Fe dan Mn.

\section{Penentuan Waktu Kontak Adsorben}

Waktu kontak terbaik merupakan waktu ketika adsorben dikontakkan dengan larutan $\mathrm{Fe}$ atau $\mathrm{Mn}$ dan menghasilkan kapasitas adsorpsi yang terbesar. Penentuan waktu optimum adsorben teraktivasi dilakukan dengan membuat larutan $\mathrm{Fe}$ konsentrasi $3 \mathrm{mg} / \mathrm{L}$ dan Mn konsentrasi 0,7 mg/L.

Hasil perhitungan kapasitas adsorpsi Fe dengan masingmasing variasi adsorben dapat dilihat pada Gambar 4.

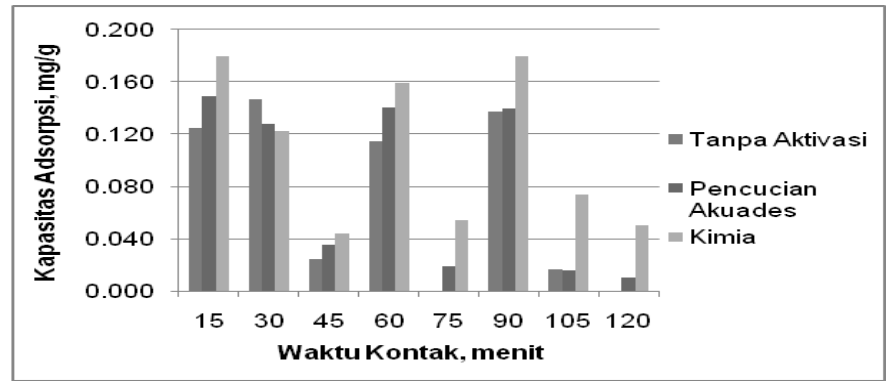

Gambar 4. Grafik kapasitas adsorpsi Fe terhadap waktu kontak

Gambar 4 menunjukkan kapasitas adsorpsi $\mathrm{Fe}$ pada adsorben dengan pencucian akuades dan aktivasi kimia terbesar terjadi pada menit ke 15 , yaitu mencapai $0,149 \mathrm{mg} / \mathrm{g}$ (adsorben pencucian akuades), 0,179 $\mathrm{mg} / \mathrm{g}$ (adsorben aktivasi kimia), dan $0,125 \mathrm{mg} / \mathrm{g}$ (adsorben tanpa aktivasi). Setelah menit ke 15, diketahui bahwa kapasitas adsorpsi semakin menurun hingga menit ke 45. Dalam medium air, ion logam khususnya untuk kation logam transisi dengan elektronegativitas yang relatif tinggi cenderung membentuk kation terhidrat dengan $\mathrm{H}_{2} \mathrm{O}$, kation-kation tersebut membentuk ikatan kovalen (koordinasi) dengan $\mathrm{H}_{2} \mathrm{O}$ dalam bentuk ion kompleks yang larut dalam air. Kompleks $\mathrm{H}_{2} \mathrm{O}$ yang terbentuk memiliki ukuran yang cukup besar sehingga kemampuan untuk terperangkap dalam adsorben menjadi kecil [12].
Hasil perhitungan kapasitas adsorpsi Mn dengan masingmasing variasi adsorben dapat dilihat pada Gambar 5.

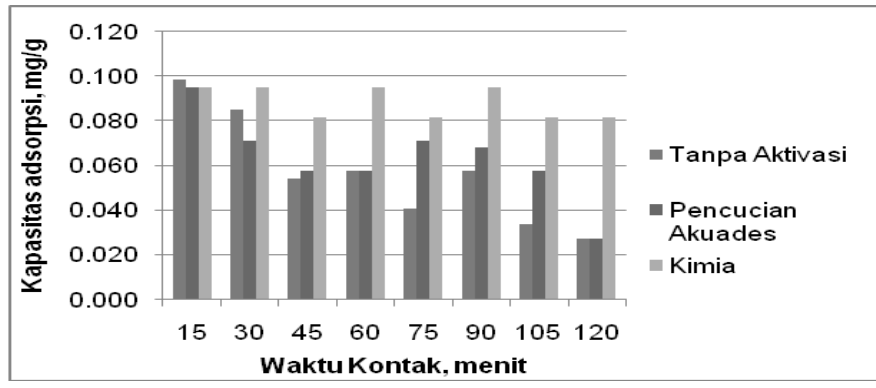

Gambar 5. Grafik kapasitas adsorpsi Mn terhadap waktu kontak

Gambar 5 menunjukkan kapasitas adsorpsi Mn terbesar yaitu pada menit ke 15 , sebesar $0,095 \mathrm{mg} / \mathrm{g}$ (adsorben pencucian akuades); $0,095 \mathrm{mg} / \mathrm{g}$ (adsorben teraktivasi kimia); dan $0,099 \mathrm{mg} / \mathrm{g}$ (adsorben tanpa aktivasi). Setelah menit ke 15, diketahui bahwa kapasitas adsorpsi mulai menurun. Penurunan kapasitas adsorpsi disebabkan oleh penggunaan alat pengaduk (shaker) dengan kecepatan yang tinggi. Penggunaan alat pengaduk dengan kecepatan tinggi dapat melepas kembali adsorbat yang telah menempel pada permukaan adsorben. Penggunaan kecepatan aduk di atas $90 \mathrm{rpm}$ akan membuat ikatan antar partikel adsorben dan adsorbat terlepas [13]. Di samping itu terlalu cepatnya pengadukan membuat adsorben tidak sempat membentuk ikatan yang kuat dengan partikel logam.

\section{Penentuan Kapasitas Adsorpsi Fe dan Mn}

Penentuan kapasitas adsorpsi dilakukan dengan menggunakan waktu kontak terbaik yang diperoleh sebelumnya. Konsentrasi larutan $\mathrm{Fe}$ yang digunakan dalam menentukan kapasitas adsorpsi yaitu 2,6;2,8; 3,0;3,2; dan 3,4 $\mathrm{mg} / \mathrm{L}$. Konsentrasi larutan Mn yang digunakan yaitu $5 ; 6 ; 7 ; 8$; dan $9 \mathrm{mg} / \mathrm{L}$. Hasil konsentrasi akhir larutan digunakan untuk menghitung efisiensi removal dan kapasitas adsorpsi yang selanjutnya dibuat dalam grafik permodelan isoterm Langmuir dan Freundlich.

Hasil perhitungan efisiensi removal $\mathrm{Fe}$ dengan masingmasing variasi adsorben dapat dilihat pada Gambar 6.

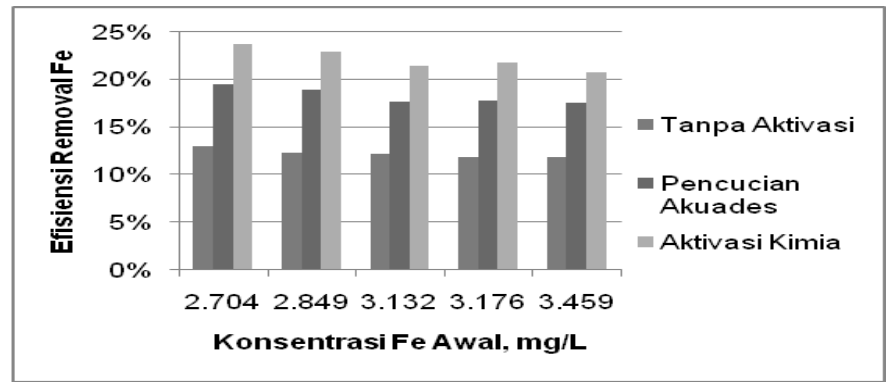

Gambar 6. Efsiensi removal Fe awal

Pada Gambar 6, diketahui bahwa efisiensi removal pada masing-masing metode aktivasi semakin menurun seiring dengan meningkatnya konsentrasi larutan $\mathrm{Fe}$ awal. Rata-rata efisiensi removal $\mathrm{Fe}$ pada adsorben tanpa aktivasi sebesar 
$12,27 \%$, adsorben dengan pencucian akuades sebesar 18,33\%, dan adsorben dengan aktivasi kimia sebesar 22,13\%.

Data hasil perhitungan kapasitas adsorpsi selanjutnya dapat digunakan untuk menentukan model isoterm adsorpsi yang sesuai. Isoterm adsorpsi yang akan ditentukan yaitu isoterm Langmuir dan Freundlich. Isoterm Langmuir mengasumsikan bahwa satu adsorbat berikatan dengan satu bagian pada adsorben dan seluruh bagian permukaan adsorben mempunyai daya tarik yang sama untuk adsorbat dengan persamaan umum:

$$
q=q m \frac{K a d s \times C}{1+K a d s \times C}
$$

Apabila ditulis dalam persamaan linier menjadi

$$
\frac{1}{q}=\frac{1}{q m \times \operatorname{Kads}}\left(\frac{1}{c}\right)+\frac{1}{q m}
$$

Isoterm Freundlich mengasumsikan bahwa satu adsorbat berikatan dengan satu bagian pada adsorben namun setiap bagian permukaan memiliki daya tarik yang berbeda pada adsorbat yang berbeda, biasa dengan persamaan:

$$
q=K \times C^{1 / n}
$$

Apabila ditulis dalam persamaan linier menjadi

$$
\log q=\log K+\frac{1}{n} \log C
$$

Hasil permodelan isoterm Langmuir proses adsorpsi $\mathrm{Fe}$ dengan masing-masing variasi adsorben dapat dilihat pada Gambar 7, 8, dan 9.

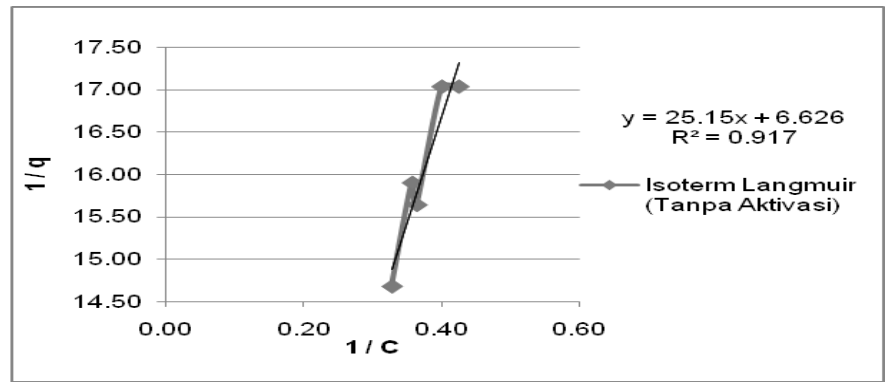

Gambar 7. Isoterm Langmuir Fe dengan adsorben tanpa aktivasi

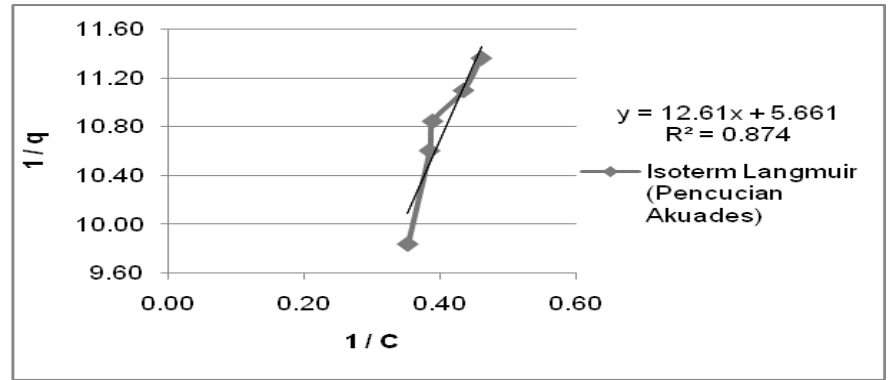

Gambar 8. Isoterm Langmuir Fe dengan adsorben pencucian akuades

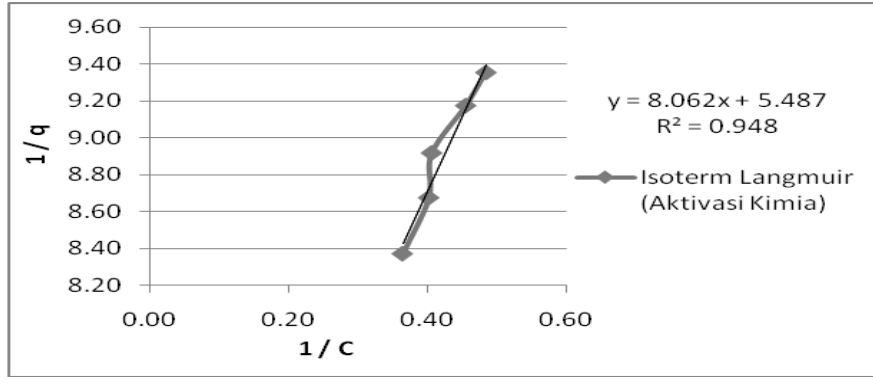

Gambar 9. Isoterm Langmuir Fe dengan adsorben aktivasi kimia

Hasil permodelan isoterm Freundlich proses adsorpsi $\mathrm{Fe}$ dengan masing-masing variasi adsorben dapat dilihat pada Gambar 10, 11, dan 12.

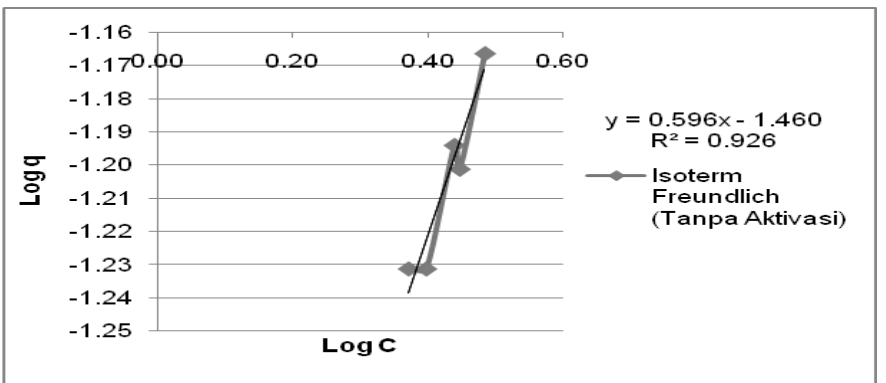

Gambar 10. Isoterm Freundlich Fe dengan adsorben tanpa aktivasi

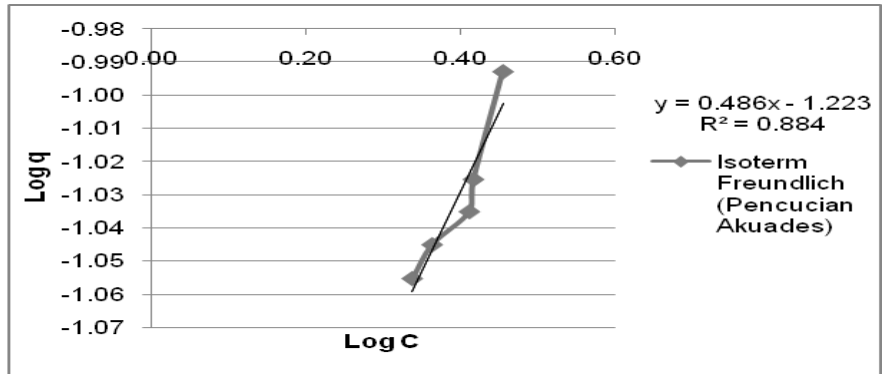

Gambar 11. Isoterm Freundlich Fe dengan adsorben pencucian akuades

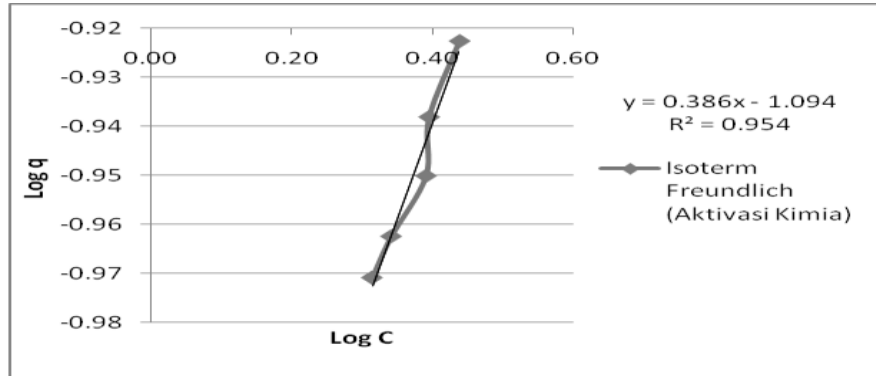

Gambar 12. Isoterm Freundlich Fe dengan adsorben aktivasi kimia

Jenis isoterm adsorpsi pada adsorben teraktivasi dapat ditentukan dengan nilai $R^{2}$ yang diperoleh. Nilai $R^{2}$ yang semakin mendekati 1 menunjukkan bahwa proses adsorpsi dapat dimodelkan dengan isoterm adsorpsi Fe. Berdasarkan Gambar 7 hingga 12, pendekatan isoterm adsorpsi Langmuir dan Freundlich pada adsorben tanpa aktivasi memiliki nilai $\mathbf{R}^{2}$ sebesar 0,917 dan 0,926. Pendekatan isoterm adsorpsi Langmuir dan Freundlich pada adsorben dengan pencucian akuades memiliki nilai $\mathrm{R}^{2}$ sebesar 0,874 dan 0,884 . Pendekatan isoterm adsorpsi pada adsorben dengan aktivasi 
kimia memiliki nilai $\mathrm{R}^{2}$ sebesar 0,948 dan 0,954 . Berdasarkan hasil tersebut, dapat diketahui bahwa nilai $\mathrm{R}^{2}$ pada masingmasing adsorben teraktivasi memiliki nilai yang mendekati 1 dengan model isoterm Freundlich. Model adsorpsi Fe dengan isoterm Freundlich menghasilkan konstanta persamaan Freundlich yang terdapat pada Tabel 1 .

Tabel 1.

Konstanta isoterm Freundlich pada adsorpsi $\mathrm{Fe}$

\begin{tabular}{lcc}
\hline \multirow{2}{*}{ Metode Aktivasi } & \multicolumn{2}{c}{ Isoterm Freundlich } \\
\cline { 2 - 3 } & $\mathrm{KF}_{\mathrm{F}}$ & $\mathrm{n}$ \\
\hline Tanpa Aktivasi & 0,035 & 1,678 \\
Pencucian Akuades & 0,060 & 2,058 \\
Aktivasi Kimia & 0,081 & 2,591 \\
\hline
\end{tabular}

Berdasarkan data tersebut dapat diketahui bahwa adsorben dengan aktivasi kimia memiliki kapasitas adsorpsi maksimum terbesar yaitu $0,182 \mathrm{mgFe} / \mathrm{g}$ adsorben. Selanjutnya yaitu adsorben dengan pencucian akuades dengan kapasitas adsorpsi maksimum sebesar $0,177 \mathrm{mgFe} / \mathrm{g}$ adsorben. Adsorben tanpa aktivasi memiliki nilaki kapasitas adsorpsi maksimum yang terkecil, yaitu sebesar $0,151 \mathrm{mgFe} / \mathrm{g}$ adsorben. Adsorben dengan aktivasi kimia juga memiliki efisiensi removal rata-rata terbesar yaitu 22,13\%, sedangkan efisiensi removal adsorben dengan pencucian akuades dan tanpa aktivasi masing-masing sebesar $18,33 \%$ dan $12,27 \%$. Sehingga dapat diketahui bahwa adsorben dengan aktivasi kimia memiliki kemampuan adsorpsi Fe yang paling besar.

Hasil perhitungan efisiensi removal Mn dengan masingmasing variasi adsorben dapat dilihat pada Gambar 13.

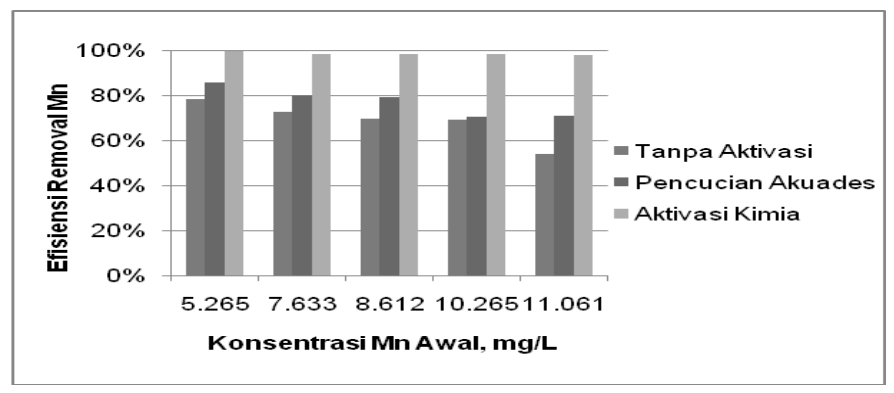

Gambar 13. Efsiensi removal Mn awal

Pada Gambar 13, diketahui bahwa efisiensi removal pada masing-masing metode aktivasi semakin menurun seiring dengan meningkatnya konsentrasi larutan $\mathrm{Mn}$ awal. Rata-rata efisiensi removal Mn pada masing-masing variasi aktivasi adsorben yaitu 68,70\% pada adsorben tanpa aktivasi, 77,20\% pada adsorben dengan pencucian akuades, dan $98,51 \%$ pada adsorben dengan aktivasi kimia. Berdasarkan hal tersebut, diketahui bahwa adsorben dengan aktivasi kimia memiliki efisiensi removal Mn yang paling tinggi, dan adsorben tanpa aktivasi memiliki efisiensi removal Mn terendah.

Data hasil perhitungan kapasitas adsorpsi selanjutnya dapat digunakan untuk menentukan model isoterm adsorpsi yang sesuai. Isoterm adsorpsi yang akan ditentukan hanya sebanyak 2 jenis model isoterm adsorpsi yaitu isoterm Langmuir dan Freundlich.

Hasil permodelan isoterm Langmuir proses adsorpsi Mn dengan masing-masing variasi adsorben dapat dilihat pada Gambar 14, 15, dan 16.

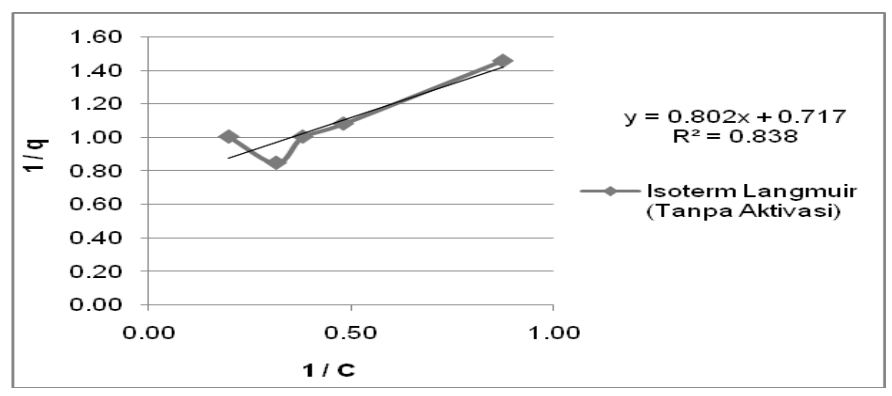

Gambar 14. Isoterm Langmuir Mn dengan adsorben tanpa aktivasi

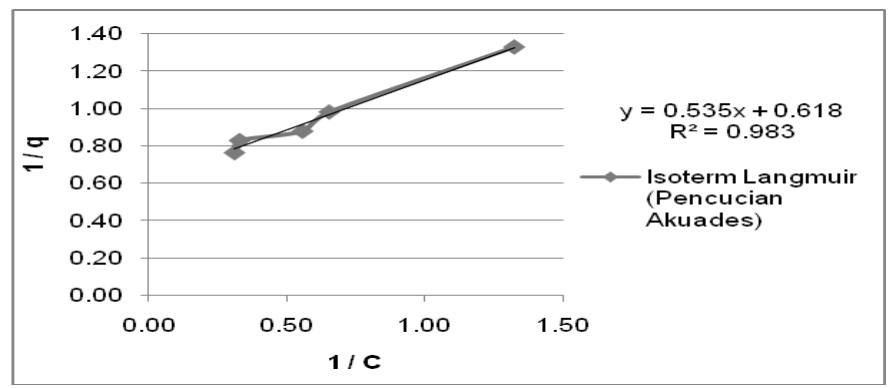

Gambar 15. Isoterm Langmuir Mn dengan adsorben pencucian akuades

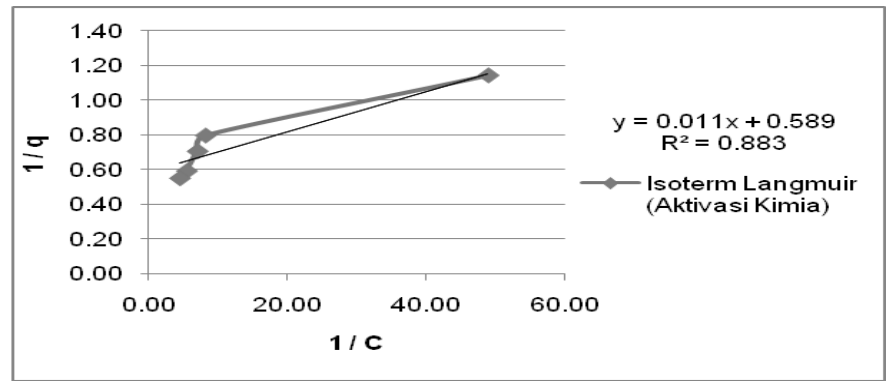

Gambar 16. Isoterm Langmuir Mn dengan adsorben aktivasi kimia

Hasil permodelan isoterm Freundlich proses adsorpsi Mn dengan masing-masing variasi adsorben dapat dilihat pada Gambar 17, 18, dan 19.

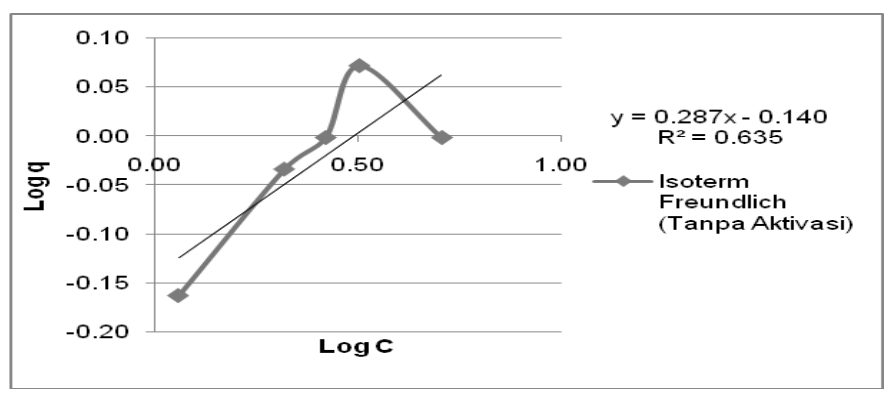

Gambar 17. Isoterm Freundlich Mn dengan adsorben tanpa aktivasi 


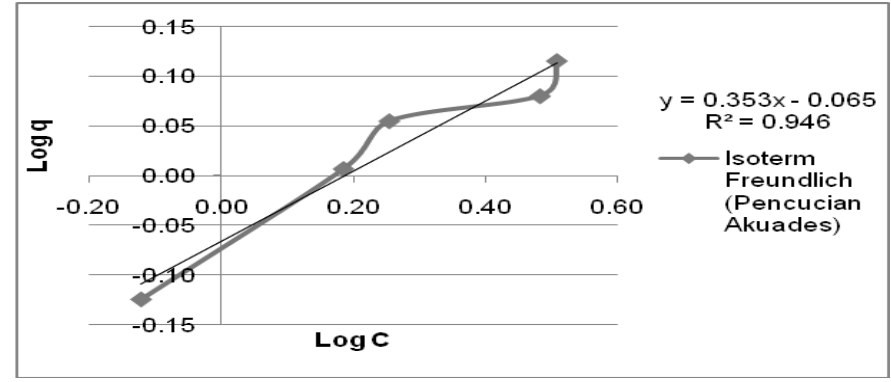

Gambar 18. Isoterm Freundlich Mn dengan adsorben pencucian akuades

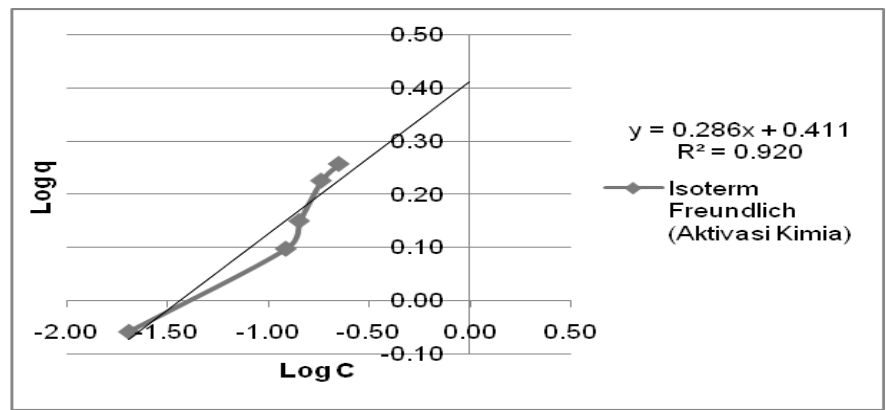

Gambar 19. Isoterm Freundlich Mn dengan adsorben aktivasi kimia

Jenis isoterm adsorpsi pada adsorben teraktivasi dapat ditentukan dengan nilai $\mathrm{R}^{2}$ yang diperoleh. Nilai $\mathrm{R}^{2}$ yang semakin mendekati 1 menunjukkan bahwa proses adsorpsi dapat dimidelkan dengan isoterm adsorpsi Mn. Berdasarkan Gambar 14 hingga 19, pendekatan isoterm adsorpsi Langmuir dan Freundlich pada adsorben tanpa aktivasi memiliki nilai $\mathbf{R}^{2}$ sebesar 0,838 dan 0,635. Pendekatan isoterm adsorpsi Langmuir dan Freundlich pada adsorben dengan pencucian akuades memiliki nilai $\mathrm{R}^{2}$ sebesar 0,983 dan 0,946 . Pendekatan isoterm adsorpsi pada adsorben dengan aktivasi kimia memiliki nilai $\mathrm{R}^{2}$ sebesar 0,883 dan 0,920 . Berdasarkan hasil tersebut, dapat diketahui bahwa nilai $\mathrm{R}^{2}$ pada masingmasing adsorben teraktivasi memiliki nilai yang mendekati 1 , sehingga dapat dimodelkan dengan isoterm adsorpsi Langmuir. Model adsorpsi Mn dengan isoterm Langmuir menghasilkan konstanta persamaan Freundlich yang terdapat pada Tabel 2.

Tabel 2.

Konstanta isoterm Langmuir pada adsorpsi Mn

\begin{tabular}{lcc}
\hline \multirow{2}{*}{ Metode Aktivasi } & \multicolumn{2}{c}{ Isoterm Langmuir } \\
\cline { 2 - 3 } & $\mathrm{q}_{\mathrm{m}}$ & $\mathrm{K}_{\mathrm{L}}$ \\
\hline Tanpa Aktivasi & 1,395 & 0,894 \\
Pencucian Akuades & 1,618 & 1,155 \\
Aktivasi Kimia & 1,698 & 53,545 \\
\hline
\end{tabular}

Berdasarkan data tersebut dapat diketahui bahwa adsorben dengan aktivasi kimia memiliki kapasitas adsorpsi maksimum terbesar yaitu $1,698 \mathrm{mgMn} / \mathrm{g}$ adsorben. Selanjutnya yaitu adsorben dengan pencucian akuades dengan kapasitas adsorpsi maksimum sebesar $1,618 \mathrm{mgMn} / \mathrm{g}$ adsorben. Adsorben tanpa aktivasi memiliki nilaki kapasitas adsorpsi maksimum yang terkecil, yaitu sebesar $1,395 \mathrm{mgMn} / \mathrm{g}$ adsorben. Adsorben dengan aktivasi kimia juga memiliki efisiensi removal rata-rata terbesar yaitu 98,51\%, sedangkan efisiensi removal adsorben dengan pencucian akuades dan tanpa aktivasi masing-masing sebesar $77,20 \%$ dan $68,70 \%$. Sehingga dapat diketahui bahwa adsorben dengan aktivasi kimia memiliki kemampuan adsorpsi Mn yang paling besar.

\section{KESIMPULAN/RINGKASAN}

Metode aktivasi kimia $\mathrm{HCl}-\mathrm{NaOH}$ pada adsorben serbuk gergaji kayu kamper menghasilkan kapasitas adsorpsi terbesar yaitu $0,182 \mathrm{mgFe} / \mathrm{g}$ dan $1,698 \mathrm{mgMn} / \mathrm{g}$ dengan rata-rata efisiensi removal terbesar yaitu $22,13 \%$ untuk Fe dan $98,51 \%$ untuk Mn. Dalam pengembangannya, adsorben serbuk gergaji kayu dapat digunakan dengan metode kontinu menggunakan kolom adsorpsi.

\section{UCAPAN TERIMA KASIH}

Penulis I.M. mengucapkan terima kasih kepada Direktorat Pendidikan Tinggi, Departemen Pendidikan dan Kebudayaan Republik Indonesia yang telah memberikan dukungan finansial melalui Beasiswa PPA tahun 2014-2015.

\section{DAFTAR PUSTAKA}

[1] P. Roccaro, C. Barone, and F. Vagliasindi, "Removal Manganese from Water Supplies Intended for Human Consumption: A Case Study," Desalination, Vol. 210 No. 1-3 (2007) 205-2014.

[2] C. Kan, M. Aganon, C. Futalan, and M. Dalida, "Adsorption of $\mathrm{Mn}^{2+}$ from Aqueous Solution Using Fe and Mn Oxide-coated Sand," Journal of Environmental Sciences, Vol. 25, No. 7 (2013) 1483-1491.

[3] A. Shukla, Y. Zhang, P. Dubey, J. Margrave, and S. Shukla, "The Role of Sawdust in The Removal of Unwanted Materials from Water," Journal of Hazardous Materials, Vol. 95, No. 1-2 (2002) 137-152.

[4] I. N. Sukarta, "Adsorpsi Ion $\mathrm{Cr}^{3+}$ oleh Serbuk Gergaji Kayu Albizia (Albizia Falcata): Studi Pengembangan Bahan Alternatif Penjerap Limbah Logam Berat," Tesis, Program Studi Kimia (2008) Sekolah Pascasarjana Institut Pertanian Bogor.

[5] Pusat Penelitian dan Pengembangan Hasil Hutan (P3HH), "Petunjuk Praktis Sifat-sifat Dasar Jenis Kayu Indonesia," Indonesia Sawmill and Woodworking Association (2008).

[6] M. Grassi, G. Kyakioglu, V. Belgiorno, and G. Lofrano. "Removal of Emerging Contaminants from Water and Wastewater by Adsorption Process," Emerging Compounds Removal from Wastewater (2012).

[7] R. Gautam, A. Mudhoo, G. Lofrano, and M. Chattopadhyaya, "Biomass-derived Biosorbents for Metal Ions Sequestration: Adsorbent Modification and Activation Methods and Adsorben Regeneration" Journal of Chemical Engineering, Vol. 2, No. 1 (2014) 239-259.

[8] U. Sulistyana, "Studi Pendahuluan Adsorpsi Kation Ca dan $\mathrm{Mg}$ (Penyebab Kesadahan) Menggunakan Selulosa Bakterial Nata De Coco dengan Metode Batch," Prosiding Skripsi Semester Genap Jurusan Kimia FMIPA ITS Surabaya (2010).

[9] J. Cavalcante, S. Rocha, and M. Luzio, "Change in Structure of Marine Algae Sargassum sp. during Drying" Brazil: $4^{\text {th }}$ Mercusor Congress on Process Systems Engineering (2005).

[10] M. Sepehr, M. Zarrabi, H. Kazemian, A. Amrane, K. Yaghmaian, and H. Ghaffari, "Removal of Hardness Agents, Calcium and Magnesium, by Natural and Alkaline Modified Pumice Stones in Single and Binary Systems,” Applied Surface Sciences, Vol. 274 (2013) 295-305.

[11] I. Safrianti, N. Wahyuni, dan T. A. Zaharah, "Adsorpsi Timbal (II) oleh Selulosa Jerami Padi Teraktivasi Asam Nitrat; Pengaruh $\mathrm{pH}$ dan Waktu Kontak," JKK, Vol. 1, No. 1 (2012) 1-7.

[12] R. Andreas, Narsito, dan S. Noegrohati, "Karakteristik Adsorpsi Tembaga (II) pada Humin dalam Medium Air Tawar," Jurnal Molekul, Vol. 1 (2006) 1-9.

[13] I. Syauqiah, M. Amalia, dan H. Kartini, "Analisis Variasi Waktu dan Kecepatan Pengaduk pada Proses Adsorpsi Limbah Logam Berat dengan Arang Aktif," Jurnal Info Teknik, Vol. 12, No. 1 (2011) 11-20. 